\title{
Leveraging HIV Care Infrastructures for Integrated Chronic Disease and Pandemic Management in Sub-Saharan Africa
}

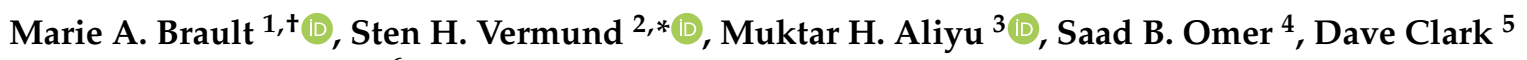 \\ and Donna Spiegelman ${ }^{6}$ \\ 1 Center for Interdisciplinary Research in AIDS, Department of Social Behavioral Sciences, Yale School of \\ Public Health, Yale University, New Haven, CT 06510, USA; marie.brault@yale.edu \\ 2 Center for Interdisciplinary Research in AIDS, Department of Epidemiology of Microbial Diseases, \\ Yale School of Public Health, Yale University, New Haven, CT 06510, USA \\ 3 Department of Health Policy, Vanderbilt Institute for Global Health, Vanderbilt University School of \\ Medicine, Nashville, TN 37232, USA; muktar.aliyu@vumc.org \\ 4 Department of Epidemiology of Microbial Diseases, Yale Institute for Global Health, Yale School of Public \\ Health, Yale University, New Haven, CT 06510, USA; saad.omer@yale.edu \\ 5 The Aurum Institute, Johannesburg 2194, South Africa; dave.clark@auruminstitute.org \\ 6 Center for Interdisciplinary Research in AIDS, Department of Biostatistics, Yale School of Public Health, \\ Yale University, New Haven, CT 06510, USA; donna.spiegelman@yale.edu \\ * Correspondence: sten.vermund@yale.edu \\ + Current affiliation: University of Texas Health Science Center, Department of Health Promotion and \\ Behavioral Sciences, School of Public Health, University of Texas, San Antonio, TX 78249, USA.
}

check for

updates

Citation: Brault, M.A.; Vermund, S.H.; Aliyu, M.H.; Omer, S.B.; Clark, D.; Spiegelman, D. Leveraging HIV Care Infrastructures for Integrated Chronic Disease and Pandemic Management in Sub-Saharan Africa. Int. J. Environ. Res. Public Health 2021, 18, 10751. https://doi.org/10.3390/ ijerph182010751

Academic Editor: Paul B. Tchounwou

Received: 6 July 2021

Accepted: 29 September 2021

Published: 13 October 2021

Publisher's Note: MDPI stays neutral with regard to jurisdictional claims in published maps and institutional affiliations.

Copyright: (c) 2021 by the authors. Licensee MDPI, Basel, Switzerland. This article is an open access article distributed under the terms and conditions of the Creative Commons Attribution (CC BY) license (https:// creativecommons.org/licenses/by/ $4.0 /)$.

\begin{abstract}
In Sub-Saharan Africa, communicable and other tropical infectious diseases remain major challenges apart from the continuing HIV/AIDS epidemic. Recognition and prevalence of noncommunicable diseases have risen throughout Africa, and the reimagining of healthcare delivery is needed to support communities coping with not only with HIV, tuberculosis, and COVID-19, but also cancer, cardiovascular disease, diabetes, and depression. Many non-communicable diseases can be prevented or treated with low-cost interventions, yet implementation of such care has been limited in the region. In this Perspective piece, we argue that deployment of an integrated service delivery model is an urgent next step, propose a South African model for integration, and conclude with recommendations for next steps in research and implementation. An approach that is inspired by South African experience would build on existing HIV-focused infrastructure that has been developed by Ministries of Health with strong support from the U.S. President's Emergency Response for AIDS Relief (PEPFAR) and the Global Fund to Fight AIDS, Tuberculosis and Malaria. An integrated chronic healthcare model holds promise to sustainably deliver infectious disease and non-communicable disease care. Integrated care will be especially critical as health systems seek to cope with the unprecedented challenges associated with COVID-19 and future pandemic threats.
\end{abstract}

Keywords: non-communicable diseases; HIV; infectious diseases; integrated care; health system strengthening; Sub-Saharan Africa

\section{Introduction}

In Sub-Saharan Africa (SSA), declining rates of extreme poverty [1,2] have been accompanied by increasing rates of non-communicable diseases (NCDs) [3-7], persistent burdens of infectious disease [8-12], and emerging pathogens such as the novel coronavirus (COVID-19) [13]. Given the magnitude of the epidemics of human immunodeficiency virus / acquired immunodeficiency syndrome (HIV / AIDS) and tuberculosis (TB), targeted resources have come from donor nations, the U.S. President's Emergency Plan for AIDS Relief (PEPFAR), the Global Fund to Fight AIDS, Tuberculosis and Malaria (Global Fund), and ministries of health to scale-up testing and treatment [14]. This investment has resulted 
in the dramatic 50\% reduction in AIDS-related deaths since 2010 in the Eastern and Southern Africa regions [8], but without commensurate NCD screening and management, there is now considerable inequity in the care of chronic diseases $[15,16]$ COVID-19 has only deepened pre-existing inequities as exemplified by slow vaccine roll-out in SSA [17,18]. Patients with COVID-19 are entering the standard health care system with modestly, at best, enhanced pandemic resources [19].

As countries cope with this historic pandemic and strive for Universal Health Coverage in the Sustainable Development Goal era, new solutions are needed to strengthen health systems, reduce inequities and siloes in service delivery, and meet the challenges posed by emerging pathogens [20]. In this brief Perspective piece, we propose renewed investment in integrated primary care to meet these needs, building on the successes of HIV programming and the Ideal Clinic model in South Africa.

The burden of NCDs in SSA is growing. Of the total burden of disease across SSA from 1990-2017, the proportion of NCDs, increased from $18.6 \%$ to $29.8 \%$ [21]. Between 10-20 million people in SSA have hypertension; if $70 \%$ were treated, 4.5 million deaths could be averted (11.5\% of global delayed deaths) [22]. After cardiovascular diseases (contributing 22.9 million Disability Adjusted Life Years (DALYs)), cancers (16.9 million DALYs) and mental disorders (13.6 million DALYs) are the next most significant contributors to the burden of NCDs in SSA [21]. A systematic review finds that population prevalence of Type 2 diabetes varies considerably across region and country, but is as high as $12 \%$ in some urban settings [23]. Morbidity and mortality due to NCDs can be prevented with known low-cost, high-impact interventions, and the World Health Organization (WHO) has developed guidelines for packages of care, such as NCD control, maternal and child health, and sexual and reproductive health and rights [24] WHO has described some of these NCD control measures as "best buys", which are clinically and cost-effective and feasible $[24,25]$ However, national guidelines too often focus on a single disease or issue, inadvertently fostering redundant infrastructures and inefficiencies. Thus, new collaborations and capacity-building will be necessary to expand existing clinical infrastructures to meet the needs of the growing NCD epidemic, which may worsen post-COVID [26] In many venues, particularly in rural SSA, we believe that integrated service delivery that incorporates NCD control into existing HIV and TB testing and treatment programs will be the key to addressing the growing NCD epidemic in SSA. Such integration will also serve as countries rebuild from COVID-19 and look ahead to future pandemic preparedness, by reducing siloed care for HIV / AIDS without consideration of competing causes of death [27].

Throughout SSA, PEPFAR and the Global Fund have partnered with Ministries of Health to establish clinics that have been effective based on multiple metrics. This PEPFAR clinical support era began in 2003-2004 and continues to support increased HIV testing and ART-based clinical care for persons living with HIV (PLHIV) and radical reductions in mother-to-child HIV transmission [28]. The scale-up of PEPFAR-funded programs helped provide ART to more than 15 million people, train over 280,000 new health workers and save over 18 million lives through 2019 [29]. From the perspective of infrastructure and sustainability, PEPFAR has also contributed to effective public-private partnerships to improve medicine supply chains and lab systems [30], as well as capacity building in developing and expanding community health worker cadres, adherence to clinical guidelines and monitoring and evaluation systems [31]. PEPFAR-funded programming has also developed key platforms for community engagement and mobilization.

Too many of these programs, however, remain obligated by funding requirements to focus on HIV and TB without deploying their logistics, facilities, and trained staff for the broader needs expressed by communities. COVID-19 has provided an opportunity to leverage the platforms designed for chronic HIV and TB care to promote COVID-related prevention (testing and contact tracing, vaccination), and encourage patients to return to primary care as COVID-related lockdowns recede [32]. Now is the time to invest in broadening their remits even further into NCDs, endemic infections, and tropical diseases, 
among others. Environmental threats related to increased vector capacities from climate warming, changing flood-drought cycles, changing air moisture capacities, and climate refugees will increase the urgency of this broader mandate for mitigation of health threats.

Despite PEPFAR's contributions to intervention development and implementation, much of this work was tightly focused on HIV / TB and not broader health systems strengthening. As PEPFAR funding and goals transition away from a vertical emergency response towards country ownership and sustainability $[33,34]$, we believe it essential that this HIV infrastructure be integrated with other health services to meet broader community needs. Treating a broader array of medical conditions will maximize the political and community support necessary to maintain HIV/TB services on the inevitable day that the U.S. Congress diminishes its PEPFAR support. As the U.S. and other donor countries confront the financial crisis sparked by the COVID-19 pandemic, these funding cuts may arrive sooner than expected.

In this Perspective piece, we provide a brief review of integrated communicable/ noncommunicable disease prevention and care models and argue that South Africa's IDEAL Clinics may offer insights for other countries seeking to extend their HIV infrastructure to address growing NCD and emerging health challenges. We conclude with recommendations for future research and implementation.

\section{Integrated Service Delivery}

There is a growing literature describing different models of successful integrated service delivery in low- and middle-income countries (LMICs) [35-39], particularly for older adults $[16,40,41]$, that could help inform the process of transitioning clinics to broader service delivery. Most of these models integrate clinical services at the point of care. However, more recent recommendations encourage further integration beyond the facility due to the common needs across levels of healthcare systems (Figure 1) [42]. Figure 1 presents common healthcare delivery needs regardless of disease type, at each level of a simplified healthcare system, from the community to the healthcare facility to the national level. Individuals, regardless of diagnosis or status, require engagement at the community level for health prevention, referral, or support. Within clinic or hospital facilities, infrastructure and clinical capacity can be used by patients, regardless of their diagnosis. At the system or national level, leadership and governance (including funding, use of data for decision-making, guideline development and implementation, and logistics and supply chain management) should not be siloed by disease.

\section{Simplified Healthcare System with Shared Needs Across Disease Type}

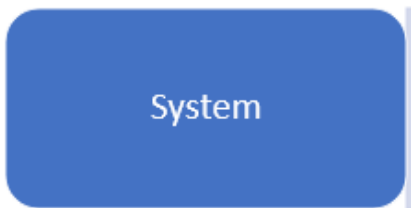

- Monitoring and evaluation to drive decision-making and funding

- Guideline implementation to support quality care

- Logistics and supply chain that supports chronic dispensing and acute needs

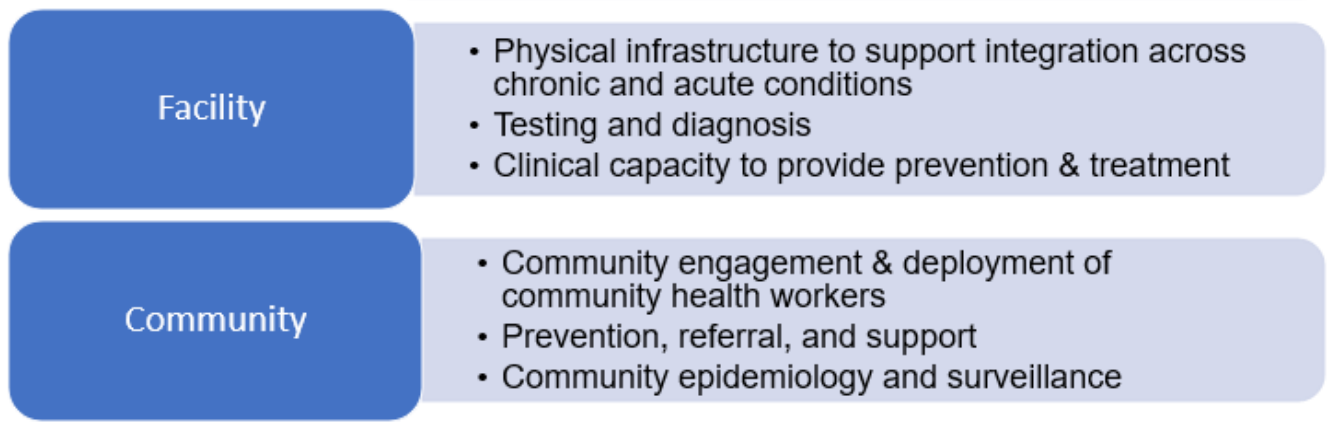

Figure 1. An overview of needs for communicable and non-communicable diseases that could be met with integration across levels of the healthcare system. 
Feasibility studies in a variety of low- and middle-income countries have shown promise in integrating HIV care with $\mathrm{TB}$, sexual and reproductive services, primary care services, and NCD screening and treatment services [35-39,43,44]. Integrating infectious and NCD services allows more individuals to be screened, treated, and retained in care for a broader range of conditions [35,36,38,43,44]. Management of HIV-exposed, uninfected children in SSA provides further examples of how integrated clinical management can be implemented, by building on HIV infrastructure. In the era of prevention of mother-to-child transmission, HIV-exposed, uninfected children remain a vulnerable group, as they are more likely to suffer from malnutrition, stunting, anemia, neurologic issues, more severe responses to common respiratory illnesses, and have higher rates of mortality even when they remain uninfected [45-52]. Cohort studies of HIV-exposed, uninfected children and pilot interventions suggest that integrated care systems that include longitudinal follow-up and monitoring, NCD screening and support (nutritional interventions, cognitive and developmental screening and support, maternal health support), and infection prevention and treatment may mitigate the negative impacts of HIV exposure [45,47,53-61].

Sustainability is supported using pre-existing infrastructure and resources. Recent costing studies of integrated care in SSA also supports the sustainability of these models. A pilot study in Tanzania and Uganda found that managing two or more conditions in a single participant was cheaper (for both the health system and the patient) than managing multiple conditions separately [62]. A study in Malawi similarly found lower out-of-pocket costs for patients in integrated care, compared to non-integrated care [63]. Intersectoral financing and /or community-based micro-financing to address both multiple determinants of health are also being explored as options to support the scale-up of integrated care $[64,65]$. Further, many elements of the health system put in place or strengthened for infectious disease prevention and treatment can be applied to NCD care and emerging pathogen needs, or vice versa (Table 1) [42,66]. Table 1 identifies elements of health system building blocks that have been strengthened through HIV capacity-building activities, and how these elements could be applied for communicable (including emerging pathogens) and non-communicable diseases.

Sufficient human resources for health are another key element of sustainable and high-quality integrated care. Task-shifting, or the use of non-physician cadres (nurses, community health workers) to provide care, has been one approach recommended in LMICs to address clinical workforce shortages. Several recent studies have assessed the feasibility, pilot effectiveness, and cost-effectiveness of task-shifting in delivering integrated primary care in SSA, both for PLHIV [56,67-74] and HIV-negative patients [75-80]. This growing literature highlights a few key recommendations for implementation. Although there is a need for more effectiveness studies of task-shifting for integrated care, the data to-date suggests that it is feasible, can contribute to improved patient experiences and follow-up, and can be a more cost-effective way to integrate NCD care $[68,71,74,75,80,81]$. At the same time, task-shifting requires effective facility managers, investment in training for non-physician cadres, and adaptation of the task-shifting approach to the context $[56,67,73,75,78,82,83]$.

Integrated care has long been defensible through a human rights lens-should a PLHIV receive optimized care whilst a person with diabetes cannot access life-saving services $[84,85]$ ? This rights-for-all strategy supports underserved persons with accountability for an improved quality of care, as is the case within the PEPFAR stratagem [86]. 
Table 1. Examples of shared needs across disease types, and ways in which HIV capacity building could be applied across these needs.

\begin{tabular}{|c|c|c|c|}
\hline $\begin{array}{l}\text { Elements of HIV } \\
\text { Capacity-Building }\end{array}$ & $\begin{array}{l}\text { Common Communicable } \\
\text { Disease Needs }\end{array}$ & $\begin{array}{l}\text { Common } \\
\text { Non-Communicable Disease } \\
\text { (NCD) Needs }\end{array}$ & $\begin{array}{l}\text { Emerging and Pandemic } \\
\text { Pathogen Needs }\end{array}$ \\
\hline Health system strengthening & $\begin{array}{l}\text { Expansion of } \\
\text { donor-supported health } \\
\text { information and } \\
\text { monitoring systems } \\
\text { beyond HIV/TB } \\
\text { - Capacity building in } \\
\text { health management and } \\
\text { quality improvement } \\
\text { Systems for } \\
\text { immunization, } \\
\text { prevention, and } \\
\text { treatment supply chains }\end{array}$ & $\begin{array}{l}\text { Data-driven approaches } \\
\text { to quality improvement } \\
\text { and supply chains } \\
\text { Clinic facility } \\
\text { improvement to support } \\
\text { screening, community } \\
\text { services, diagnosis and } \\
\text { treatment for simple } \\
\text { NCDs } \\
\text { Systems for chronic } \\
\text { disease medication } \\
\text { dispensing }\end{array}$ & 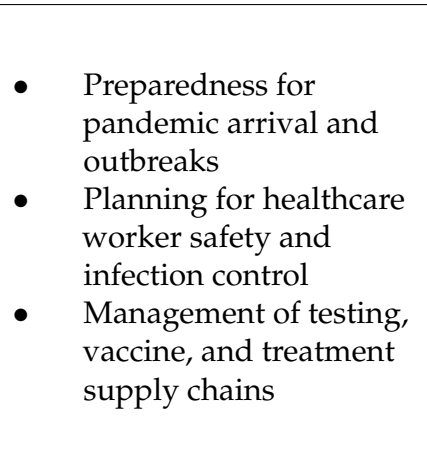 \\
\hline $\begin{array}{l}\text { Clinical capacity for } \\
\text { management of complex } \\
\text { patients }\end{array}$ & $\begin{array}{l}\text { Prevention through } \\
\text { pre-exposure } \\
\text { prophylaxis } \\
\text { Management of HIV and } \\
\text { related opportunistic } \\
\text { infections } \\
\text { Modify care per } \\
\text { immunologic, virologic, } \\
\text { and clinical response to } \\
\text { antiretroviral therapies } \\
\text { and other therapies } \\
\text { Retention and follow-up } \\
\text { services }\end{array}$ & 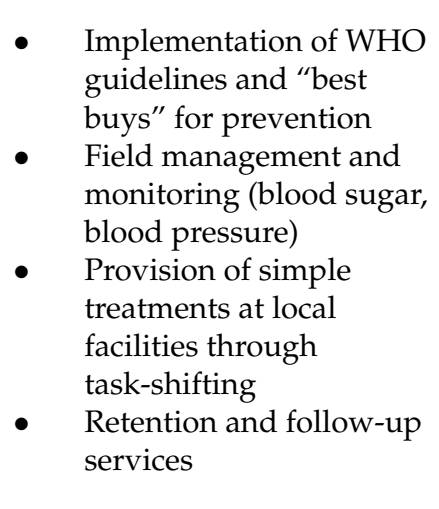 & $\begin{array}{ll}\text { - } & \text { Case recognition and } \\
\text { rapid diagnosis to } \\
\text { facilitate contact tracing } \\
\text { - } \quad \text { Implementation of } \\
\text { infection control } \\
\text { guidelines } \\
\text { Evidence-based } \\
\text { implementation and } \\
\text { review of management } \\
\text { and treatment guidelines }\end{array}$ \\
\hline $\begin{array}{l}\text { Laboratories and point-of-care } \\
\text { testing, diagnosis, monitoring }\end{array}$ & $\begin{array}{l}\text { Diagnosis of HIV and } \\
\text { related diseases } \\
\text { Monitoring CD } 4^{+} \text {cells, } \\
\text { virologic, metabolic and } \\
\text { hematologic parameters } \\
\text { related to common } \\
\text { treatments }\end{array}$ & 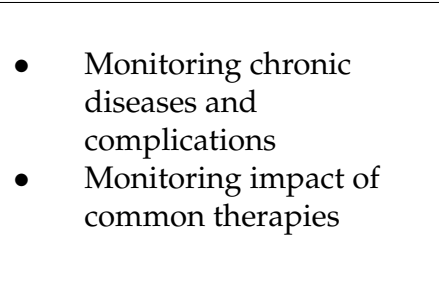 & $\begin{array}{l}\text { Diagnosis of emerging } \\
\text { and re-emerging } \\
\text { pathogens } \\
\text { Sequencing and } \\
\text { monitoring for variants } \\
\text { of concern }\end{array}$ \\
\hline $\begin{array}{l}\text { Community engagement and } \\
\text { referral, local delivery of } \\
\text { interventions }\end{array}$ & $\begin{array}{l}\text { Development of } \\
\text { community advisory and } \\
\text { governance structures } \\
\text { Distribution of } \\
\text { prevention and } \\
\text { treatment tools (e.g., } \\
\text { directly observed } \\
\text { therapy (short course), } \\
\text { condoms, mosquito nets) }\end{array}$ & $\begin{array}{l}\text { - Community-based } \\
\text { prevention and } \\
\text { adherence support } \\
\text { - Linkages between } \\
\text { community and facility } \\
\text { for prevention and } \\
\text { treatment }\end{array}$ & $\begin{array}{l}\text { - Contact tracing and } \\
\text { support for quarantine } \\
\text { - Home-based care for less } \\
\text { severe illness } \\
\text { - Linkage to testing, } \\
\text { vaccination, medical } \\
\text { treatment }\end{array}$ \\
\hline
\end{tabular}

\section{A South African Model}

We suggest one approach for implementation of such integrated care. South Africa's IDEAL clinics provide a promising model of integrated HIV/NCD care that could be scaled-up and replicated elsewhere in SSA. The IDEAL Clinic Realisation and Management (ICRM) initiative began in 2013 as part of a series of reforms to implement a National Health Insurance System, expand Universal Health Coverage, and systematically improve South Africa's primary care clinics [87]. The NCD component of the IDEAL clinic initiative was piloted from 2011-2013 in a sub-set of districts, with promising results, leading to its inclusion in the IDEAL clinic guidelines [88]. However, the concept of integrated primary care as proposed by the ICRM is not new to South Africa. In the mid-20th century, Sidney 
and Emily Kark and collaborators developed the concept of community-oriented primary care in rural South Africa, integrating both preventive and curative services based on the needs of local communities $[89,90]$. The IDEAL Clinics represent a modern re-imagining of these concepts [91,92].

A set of tools comprising a manual and an electronic dashboard support the implementation of integrated services and certification as an IDEAL clinic [87]. To receive IDEAL clinic certification, a facility must achieve a metrics score indicating successful implementation of key elements. These elements include good infrastructure; adequate staff; adequate medicine and supplies; strong administrative processes including use of appropriate clinical guidelines and protocols; partner and stakeholder engagement to ensure delivery of high-quality care to the community; and integrated clinical services management that "builds on the strengths of the HIV program to deliver integrated care to patients with chronic and/or acute diseases" [87].

The ICRM process requires that primary care facility managers conduct routine assessments of progress towards certification. Quality improvement plans are then developed to guide further planning and implementation. However, much work is needed, as the implementation of the standards has been slower than planned, and evaluations of the integrated care approach have produced mixed results. As of 2018/2019 (the most recent data available), $55.4 \%$ of primary care facilities had achieved IDEAL certification [93]. Two recent studies attribute the slow implementation, in part, to limited governance and leadership that has contributed to poor communication, resource constraints, limited input from frontline managers and staff, and limited accountability [94,95].

Some studies of the IDEAL model have noted that HIV stigma has been reduced by treating both HIV positive and negative patients in the same facilities [96-98]. However, implementation across facilities has been uneven, with some facilities better able to implement guidelines with higher fidelity, due primarily to better training and clinical mentorship [99]. Other facilities experience continued deficiencies in facility staffing, physical space, medicines, and equipment that have contributed to limited effectiveness and patient satisfaction $[97,100]$. Further, studies suggest that although integrated care can be helpful for delivering HIV treatment [101], it is also associated with decreases in new hypertension patients on treatment, due to added burdens placed on a weak primary care system [102]. These mixed findings, combined with a previous review of integration identifying limitations in the data $[37,103]$, suggest that additional work is needed to systematically implement, evaluate, and disseminate integrated care models, such as the IDEAL clinics across SSA. Furthermore, like all systems interventions, they are difficult to sustain since systems regress too readily-but where they are sustained, patients report a much higher level of satisfaction with services received [104].

\section{Discussion}

Despite the challenges associated with shifting to integrated services, the Ugandan and Kenyan SEARCH (Sustainable East Africa Research in Community Health) trial demonstrates how quickly NCD care can be integrated within HIV services with community and health system mobilization $[105,106]$. In the SEARCH study, HIV treatment as prevention was integrated with diabetes and hypertension screening and management in rural communities with some success in hypertension control [44] However, SEARCH faced challenges in linking and retaining screened patients in care, raising questions regarding the long-term feasibility, scalability, and sustainability of this grant-funded approach, requiring additional implementation studies [105]. Many HIV services in other settings have already made the transition to broad-based NCD care and are actively working to engage the whole patient population in addition to the PLHIV they originally served $[107,108]$. Throughout the continent, African Ministries of Health have called upon their HIV / AIDS-capacitated laboratories, public health experts, and clinicians to address health service stresses from emerging pandemic threats, whether Ebola virus in West Africa and Congo or COVID-19 in 
South Africa or Nigeria $[19,109,110]$. Similarly, NCDs and pandemic preparedness efforts can draw upon the capacity-building accomplished in the HIV / AIDS response.

The time has come to broaden the PEPFAR-developed care capacity to embrace the universal health challenges of modern Africa. Over a decade ago, the U.S. President's Global Health Initiative in the Barack Obama Administration had a similar vision [111,112] but was never funded substantially by the U.S. Congress. The current COVID-19 pandemic underscores with some urgency the need for the integration of the high-quality HIV treatment and care services (including community-based health workers and contact tracers) with other primary care services, including those concerning COVID-19 [4]. Health systems strengthening that can remedy the challenges facing health care systems throughout Sub-Saharan Africa would enable sustainable capacity for diverse endemic and epidemic threats $[4,113,114]$. Attempts to broaden this capacity should include input from ministries of health, policy experts, researchers, community-based organizations, and other stakeholders, in addition to considerations of sustainability and robust evaluation of the impact of integration on key HIV, emerging infectious diseases, and NCD indicators.

We believe that the urgency for such transformation of more broadly based primary health care is exacerbated by global warming and climate change that will increasingly strain communities through displaced populations, adverse effects on crops, fish, and grazing animals $[115,116]$, direct temperature and environmental effects on vulnerable populations [117-119], expanded vectorial capacities of disease-relevant arthropods and snails [120], and mental health stresses [121]. Health systems must be ready to cope with existing and expanding health challenges, particularly in lower income nations. A recent example is the urgency of SARS-CoV-2 vaccination to prevention COVID-19. The more global transmission, the greater the likelihood of escape mutant RNA viruses such that only a truly global and effective response that subsumes low- and middle-income nations will resolve the pandemic [122-125]. Fortunately, PEPFAR managers have embraced the need to consider COVID-19 as part of an HIV / AIDS/TB remit [21].

There will be many obstacles for which HIV/AIDS/TB quality improvement and capacity research can inform more integrated programs [48,126-128]. Communities and patients themselves are vital contributors to systems improvement through program integrations and community participation [129-131]. Despite the challenges associated with integrated care, the IDEAL Clinic and similar approaches offer insights into how existing resources can be leveraged to provide comprehensive primary care in LMICs.

\section{Conclusions}

We believe now is the time for the razor focus of PEPFAR and Global Fund-supported HIV / AIDS/TB clinical services to pivot towards integrated care inclusive of a wider swathe of NCDs and pandemic threats. As we have detailed here, approaches for integrated care exist and offer promise for further adaptation and scale-up throughout Sub-Saharan Africa. Although health system limitations (including human and financial resources) present challenges to the implementation of integrated care, there is growing evidence that integrated care can be more efficient than vertical programming. Broader support from policymakers and communities alike can be expected when integrated services are provided. Broader high-quality service provision may also incentivize healthcare workers to contribute locally rather than migrate abroad [132-134]. Future financial assessments can estimate both added medical care costs as well as cost savings from early interventions with primary care and responses to emerging diseases. Further evaluation of integrated care to inform implementation and scale-up can support expanded care for communities dealing with burdens of communicable, non-communicable, and emerging diseases. 
Author Contributions: Conceptualization, S.H.V., M.H.A., S.B.O., D.C., D.S.; methodology, N/A; software, N/A; validation, N/A; formal analysis, N/A; investigation: N/A; resources, N/A; data curation, N/A; writing—original draft preparation, M.A.B., S.H.V., M.H.A., D.C., D.S.; writingreview and editing, M.A.B., S.H.V., M.H.A., D.C., D.S.; visualization, M.A.B., S.H.V.; supervision, $\mathrm{N} / \mathrm{A}$; project administration, N/A; funding acquisition, N/A. All authors have read and agreed to the published version of the manuscript.

Funding: M.A.B. is funded by NIH award K01TW011480.

Institutional Review Board Statement: Not applicable.

Informed Consent Statement: Not applicable.

Data Availability Statement: No new data were created or analyzed in this study. Data sharing is not applicable to this article.

Conflicts of Interest: The authors declare no conflict of interests.

\section{References}

1. Fosu, A.K. Growth, Inequality and Poverty in Sub-Saharan Africa: Recent Progress in a Global Context. Oxf. Dev. Stud. 2015, 43, 44-59. [CrossRef]

2. Bicaba, Z.; Brixiová, Z.; Ncube, M. Can Extreme Poverty in Sub-Saharan Africa be Eliminated by 2030? J. Afr. Dev. 2017, 19, 93-110.

3. Zhou, B.; Perel, P.; Mensah, G.A.; Ezzati, M. Global epidemiology, health burden and effective interventions for elevated blood pressure and hypertension. Nat. Rev. Cardiol. 2021, 2021, 1-18. [CrossRef]

4. Ake, J.A.; Polyak, C.S.; Crowell, T.A.; Kiweewa, F.; Semwogerere, M.; Maganga, L.; Bahemana, E.; Maswai, J.; Langat, R.; Owuoth, J.; et al. Noninfectious Comorbidity in the African Cohort Study. Clin. Infect. Dis. 2018, 69, 639-647. [CrossRef] [PubMed]

5. Yaya, S.; Ekholuenetale, M.; Bishwajit, G. Differentials in prevalence and correlates of metabolic risk factors of non-communicable diseases among women in sub-Saharan Africa: Evidence from 33 countries. BMC Public Health 2018, 18, 1168. [CrossRef] [PubMed]

6. Zhang, X.; Zeng, Q.; Cai, W.; Ruan, W. Trends of cervical cancer at global, regional, and national level: Data from the Global Burden of Disease study 2019. BMC Public Health 2021, 21, 894. [CrossRef]

7. Anyigba, C.A.; Awandare, G.A.; Paemka, L. Breast cancer in sub-Saharan Africa: The current state and uncertain future. Exp. Biol. Med. 2021, 246, 1377-1387. [CrossRef] [PubMed]

8. UNAIDS. UNAIDS Global AIDS Update 2021; UNAIDS: Geneva, Switzerland, 2021

9. Martial, N.T.; Mubarik, S.; Yu, C. Long-term trends of tuberculosis incidence and mortality in four central African countries. Sci. Rep. 2021, 11, 16624. [CrossRef] [PubMed]

10. Osman, M.; Karat, A.S.; Khan, M.; Meehan, S.-A.; von Delft, A.; Brey, Z.; Charalambous, S.; Hesseling, A.C.; Naidoo, P.; Loveday, M. Health system determinants of tuberculosis mortality in South Africa: A causal loop model. BMC Health Serv. Res. 2021, 21, 388. [CrossRef]

11. Lungu, P.; Kerkhoff, A.D.; Kasapo, C.C.; Mzyece, J.; Nyimbili, S.; Chimzizi, R.; Silumesii, A.; Kagujje, M.; Subbaraman, R.; Muyoyeta, M.; et al. Tuberculosis care cascade in Zambia-Identifying the gaps in order to improve outcomes: A population-based analysis. BMJ Open 2021, 11, e044867. [CrossRef] [PubMed]

12. Weber, A.-C.; Bogler, L.; Vollmer, S.; Simen-Kapeu, A.; Ekpini, R.E.; Zagre, N.M. The wealth gradient in diarrhoea, acute respiratory infections, and malaria in childhood over time: A descriptive analysis using DHS and MICS from Western and Central Africa between 1995 and 2017. J. Glob. Health 2021, 11, 13009. [CrossRef] [PubMed]

13. Africa CDC COVID-19 Dashboard [Database on the Internet]. African Union. 2021. Available online: https://africacdc.org/ covid-19/ (accessed on 15 September 2021).

14. Brault, M.A.; Spiegelman, D.; Abdool Karim, S.S.; Vermund, S.H. Integrating and Interpreting Findings from the Latest Treatment as Prevention Trials. Curr. HIV/AIDS Rep. 2020, 17, 249-258. [CrossRef] [PubMed]

15. Otieno, G.; Whiteside, Y.O.; Achia, T.; Kwaro, D.; Zielinski-Gutierrez, E.; Ojoo, S.; Sewe, M.; Musingila, P.; Akelo, V.; Obor, D.; et al. Decreased HIV-associated mortality rates during scale-up of antiretroviral therapy, 2011-2016. AIDS 2019, 33, 2423-2430. [CrossRef] [PubMed]

16. Levitt, N.S.; Steyn, K.; Dave, J.; Bradshaw, D. Chronic noncommunicable diseases and HIV-AIDS on a collision course: Relevance for health care delivery, particularly in low-resource settings-Insights from South Africa. Am. J. Clin. Nutr. 2011, 94, 1690S-1696S. [CrossRef]

17. World Health Organization (WHO). WHO Coronavirus (COVID-19) Dashboard; World Health Organization: Geneva, Switzerland, 2021. Available online: https:/ / covid19.who.int/ (accessed on 7 June 2021).

18. Hatchett, R.; Berkley, S.; Ghebreyesus, T.; Fore, H. COVAX Joint Statement: Call to action to equip COVAX to deliver 2 billion doses in 2021. In World Health Organization News; WHO: Geneva, Switzerland, 2021. 
19. Patel, L.N.; Kozikott, S.; Ilboudo, R.; Kamateeka, M.; Lamorde, M.; Subah, M.; Tsiouris, F.; Vorndran, A.; Lee, C.T. Safer primary healthcare facilities are needed to protect healthcare workers and maintain essential services: Lessons learned from a multicountry COVID-19 emergency response initiative. BMJ Glob. Health 2021, 6, e005833. [CrossRef] [PubMed]

20. Boggs, D.; Polack, S.; Kuper, H.; Foster, A. Shifting the focus to functioning: Essential for achieving Sustainable Development Goal 3, inclusive Universal Health Coverage and supporting COVID-19 survivors. Glob. Health Action 2021, 14, 1903214. [CrossRef]

21. Gouda, H.N.; Charlson, F.; Sorsdahl, K.; Ahmadzada, S.; Ferrari, A.J.; Erskine, H.; Leung, J.; Santamauro, D.; Lund, C.; Aminde, L.N.; et al. Burden of non-communicable diseases in sub-Saharan Africa, 1990-2017: Results from the Global Burden of Disease Study 2017. Lancet Glob. Health 2019, 7, e1375-e1387. [CrossRef]

22. Kontis, V.; Cobb, L.K.; Mathers, C.D.; Frieden, T.R.; Ezzati, M.; Danaei, G. Three Public Health Interventions Could Save 94 Million Lives in 25 Years. Circulation 2019, 140, 715-725. [CrossRef]

23. Hall, V.; Thomsen, R.W.; Henriksen, O.; Lohse, N. Diabetes in Sub Saharan Africa 1999-2011: Epidemiology and public health implications. a systematic review. BMC Public Health 2011, 11, 564. [CrossRef] [PubMed]

24. WHO; World Economic Forum. From Burden to "Best Buys": Reducing the Economic Impact of Non-Communicable Diseaes in Low-and Middle-Income Countries; WHO: Geneva, Switzerland, 2011.

25. Zarocostas, J. WHO lists "best buys" for cutting deaths from non-communicable disease. BMJ 2011, 342, d2648. [CrossRef]

26. Abila, D.B.; Ainembabazi, P.; Wabinga, H. COVID-19 pandemic and the widening gap to access cancer services in Uganda. Pan Afr. Med. J. 2020, 35, 140. [CrossRef]

27. Solanki, G.; Kelly, G.; Cornell, J.; Geffen, L.; Doherty, T. The need to incorporate the impact of population ageing into the post-COVID-19 policy and planning reset in Low and Middle Income Countries. Glob. Health Action 2021, 14, 1921351. [CrossRef] [PubMed]

28. Bendavid, E. Past and Future Performance: PEPFAR in the Landscape of Foreign Aid for Health. Curr. HIV/AIDS Rep. 2016, 13, 256-262. [CrossRef] [PubMed]

29. US Department of State. The United States President's Emergency Plan for AIDS Relief (PEPFAR) 2019 Annual Report to Congress; US Department of State, Ed.; U.S. Department of State: Washington, DC, USA, 2019.

30. Sturchio, J.L.; Cohen, G.M. How PEPFAR's Public-Private Partnerships Achieved Ambitious Goals, From Improving Labs to Strengthening Supply Chains. Health Aff. 2012, 31, 1450-1458. [CrossRef]

31. Porter, L.E.; Bouey, P.D.; Curtis, S.; Hochgesang, M.; Idele, P.; Jefferson, B.; Lemma, W.; Myrick, R.; Nuwagaba-Biribonwoha, H.; Prybylski, D.; et al. Beyond indicators: Advances in global HIV monitoring and evaluation during the PEPFAR era. J. Acquir. Immune Defic. Syndr. 2012, 60 (Suppl. 3), S120-S126. [CrossRef] [PubMed]

32. Golin, R.; Godfrey, C.; Firth, J.; Lee, L.; Minior, T.; Phelps, B.R.; Raizes, E.G.; Ake, J.A.; Siberry, G.K. PEPFAR's response to the convergence of the HIV and COVID-19 pandemics in Sub-Saharan Africa. J. Int. AIDS Soc. 2020, 23, e25587. [CrossRef]

33. Goosby, E.; Von Zinkernagel, D.; Holmes, C.; Haroz, D.; Walsh, T. Raising the bar: PEPFAR and new paradigms for global health J. Acquir. Immune Defic. Syndr. 2012, 60 (Suppl. 3), S158-S162. [CrossRef]

34. Vogus, A.; Graff, K. PEPFAR Transitions to Country Ownership: Review of Past Donor Transitions and Application of Lessons Learned to the Eastern Caribbean. Glob. Health Sci. Pract. 2015, 3, 274-286. [CrossRef]

35. Janssens, B.; Van Damme, W.; Raleigh, B.; Gupta, J.; Khem, S.; Ty, K.S.; Vun, M.C.; Ford, N.; Zachariah, R. Offering integrated care for HIV/AIDS, diabetes and hypertension within chronic disease clinics in Cambodia. Bull. World Health Organ. 2007, 85, 880-885. [CrossRef]

36. Topp, S.M.; Chipukuma, J.M.; Giganti, M.; Mwango, L.K.; Chiko, L.M.; Tambatamba-Chapula, B.; Wamulume, C.S.; Reid, S. Strengthening Health Systems at Facility-Level: Feasibility of Integrating Antiretroviral Therapy into Primary Health Care Services in Lusaka, Zambia. PLoS ONE 2010, 5, e11522. [CrossRef]

37. Njuguna, B.; Vorkoper, S.; Patel, P.; Reid, M.J.; Vedanthan, R.; Pfaff, C.; Park, P.H.; Fischer, L.; Laktabai, J.; Pastakia, S.D. Models of integration of HIV and noncommunicable disease care in sub-Saharan Africa: Lessons learned and evidence gaps. AIDS 2018, 32 (Suppl. 1), S33-S42. [CrossRef]

38. Maitra, S.; Brault, M.A.; Schensul, S.L.; Schensul, J.J.; Nastasi, B.K.; Verma, R.K.; Burleson, J.A. An Approach to Mental Health in Low- and Middle-Income Countries: A Case Example from Urban India. Int. J. Ment. Health 2015, 44, 215-230. [CrossRef] [PubMed]

39. Duffy, M.; Ojikutu, B.; Andrian, S.; Sohng, E.; Minior, T.; Hirschhorn, L.R. Non-communicable diseases and HIV care and treatment: Models of integrated service delivery. Trop. Med. Int. Health 2017, 22, 926-937. [CrossRef] [PubMed]

40. Kintu, A.; Sando, D.; Okello, S.; Mutungi, G.; Guwatudde, D.; Menzies, N.A.; Danaei, G.; Verguet, S. Integrating care for non-communicable diseases into routine HIV services: Key considerations for policy design in sub-Saharan Africa. J. Int. AIDS Soc. 2020, 23, e25508. [CrossRef] [PubMed]

41. Naidoo, K.; Van Wyk, J. What the elderly experience and expect from primary care services in KwaZulu-Natal, South Africa. Afr. J. Prim. Health Care Fam. Med. 2019, 11, e1-e6. [CrossRef]

42. National Academies of Sciences, Engineering, \& Medicine. The Convergence of Infectious Diseases and Noncommunicable Diseases: Proceedings of a Workshop; Ogawa, V.A., Shah, C.M., Negussie, Y., Nicholson, A., Eds.; The National Academies Press: Washington, DC, USA, 2019. 
43. Shenoi, S.V.; Moll, A.P.; Brooks, R.P.; Kyriakides, T.; Andrews, L.; Kompala, T.; Upadhya, D.; Altice, F.; Eksteen, F.J.; Friedland, G. Integrated Tuberculosis/Human Immunodeficiency Virus Community-Based Case Finding in Rural South Africa: Implications for Tuberculosis Control Efforts. Open Forum Infect. Dis. 2017, 4, ofx092. [CrossRef]

44. Havlir, D.V.; Balzer, L.B.; Charlebois, E.D.; Clark, T.D.; Kwarisiima, D.; Ayieko, J.; Kabami, J.; Sang, N.; Liegler, T.; Chamie, G.; et al. HIV Testing and Treatment with the Use of a Community Health Approach in Rural Africa. N. Engl. J. Med. 2019, 381, $219-229$. [CrossRef]

45. Patel, M.R.; Mushavi, A.; Balachandra, S.; Shambira, G.; Nyakura, J.; Mugurungi, O.; Kilmarx, P.H.; Rivadeneira, E.; Dinh, T.-H. HIV-exposed uninfected infant morbidity and mortality within a nationally representative prospective cohort of mother-infant pairs in Zimbabwe. AIDS 2020, 34, 1339-1346. [CrossRef]

46. Duffy, C.; Kenga, D.B.; Gebretsadik, T.; Maússe, F.E.; Manjate, A.; Zaqueu, E.; Fernando, H.F.; Green, A.F.; Sacarlal, J.; Moon, T.D. Multiple Concurrent Illnesses Associated with Anemia in HIV-Infected and HIV-Exposed Uninfected Children Aged 6-59 Months, Hospitalized in Mozambique. Am. J. Trop. Med. Hyg. 2020, 102, 605-612. [CrossRef]

47. Slogrove, A.L.; Powis, K.M.; Johnson, L.F.; Stover, J.; Mahy, M. Estimates of the global population of children who are HIV-exposed and uninfected, 2000-2018: A modelling study. Lancet Glob. Health 2020, 8, e67-e75. [CrossRef]

48. Carlucci, J.G.; Liu, Y.; Friedman, H.; E Pelayo, B.; Robelin, K.; Sheldon, E.K.; Clouse, K.; Vermund, S.H. Attrition of HIV-exposed infants from early infant diagnosis services in low- and middle-income countries: A systematic review and meta-analysis. J. Int. AIDS Soc. 2018, 21, e25209. [CrossRef] [PubMed]

49. Sofeu, C.L.; Tejiokem, M.C.; Penda, C.I.; Protopopescu, C.; Ndongo, F.A.; Ndiang, S.T.; Guemkam, G.; Warszawski, J.; Faye, A.; Giorgi, R.; et al. Early treated HIV-infected children remain at risk of growth retardation during the first five years of life: Results from the ANRS-PEDIACAM cohort in Cameroon. PLoS ONE 2019, 14, e0219960. [CrossRef] [PubMed]

50. Ntozini, R.; Chandna, J.; Evans, C.; Chasekwa, B.; Majo, F.D.; Kandawasvika, G.; Tavengwa, N.V.; Mutasa, B.; Mutasa, K.; Moulton, L.H.; et al. Early child development in children who are HIV-exposed uninfected compared to children who are HIV-unexposed: Observational sub-study of a cluster-randomized trial in rural Zimbabwe. J. Int. AIDS Soc. 2020, 23, e25456. [CrossRef]

51. Crowell, C.S.; Williams, P.L.; Yildirim, C.; Van Dyke, R.B.; Smith, R.; Chadwick, E.G.; Seage, G.R.; Diperna, A.; Hazra, R. Safety of in-utero antiretroviral exposure: Neurologic outcomes in children who are HIV-exposed but uninfected. AIDS 2020, 34, $1377-1387$. [CrossRef]

52. Scrymgeour-Wedderburn, C.; Yeung, S.; Rehman, A.; Stadler, J.A.M.; Nhapi, R.T.; Barnett, W.; Myer, L.; Gibb, D.M.; Zar, H.; Stein, D.; et al. Neurodevelopment of HIV-exposed uninfected children in South Africa: Outcomes from an observational birth cohort study. Lancet Child Adolesc. Health 2019, 3, 803-813. [CrossRef]

53. Goga, A.E.; Lombard, C.; Jackson, D.; Ramokolo, V.; Ngandu, N.K.; Sherman, G.; Puren, A.; Chirinda, W.; Bhardwaj, S.; Makhari, N.; et al. Impact of breastfeeding, maternal antiretroviral treatment and health service factors on 18-month vertical transmission of HIV and HIV-free survival: Results from a nationally representative HIV-exposed infant cohort, South Africa. J. Epidemiol. Community Health 2020, 74, 1069-1077. [CrossRef]

54. Ramokolo, V.; Goga, A.E.; Slogrove, A.; Powis, K.M. Unmasking the vulnerabilities of uninfected children exposed to HIV. BMJ 2019, 366, 14479. [CrossRef]

55. Le Roux, S.M.; Abrams, E.J.; Nguyen, K.; Myer, L. Clinical outcomes of HIV-exposed, HIV-uninfected children in sub-Saharan Africa. Trop. Med. Int. Health TM IH 2016, 21, 829-845. [CrossRef]

56. Marotta, C.; Giaquinto, C.; Di Gennaro, F.; Chhaganlal, K.D.; Saracino, A.; Moiane, J.; Maringhini, G.; Pizzol, D.; Putoto, G.; Monno, L.; et al. Pathways of care for HIV infected children in Beira, Mozambique: Pre-post intervention study to assess impact of task shifting. BMC Public Health 2018, 18, 703. [CrossRef]

57. Ajibola, G.; Bennett, K.; Powis, K.M.; Hughes, M.D.; Leidner, J.; Kgole, S.; Batlang, O.; Mmalane, M.; Makhema, J.; Lockman, S.; et al. Decreased diarrheal and respiratory disease in HIV exposed uninfected children following vaccination with rotavirus and pneumococcal conjugate vaccines. PLOS ONE 2020, 15, e0244100. [CrossRef] [PubMed]

58. Rotheram-Borus, M.J.; Christodoulou, J.; Rezvan, P.H.; Comulada, W.S.; Gordon, S.; Skeen, S.; Stewart, J.; Almirol, E.; Tomlinson, M. Maternal HIV does not affect resiliency among uninfected/HIV exposed South African children from birth to 5 years of age. AIDS 2019, 33, S5-S16. [CrossRef] [PubMed]

59. Tomlinson, M.; Rotheram-Borus, M.J.; Le Roux, I.M.; Youssef, M.; Nelson, S.H.; Scheffler, A.; Weiss, R.E.; O'Connor, M.; Worthman, C.M. Thirty-Six-Month Outcomes of a Generalist Paraprofessional Perinatal Home Visiting Intervention in South Africa on Maternal Health and Child Health and Development. Prev. Sci. 2016, 17, 937-948. [CrossRef] [PubMed]

60. Archary, M.; Fairlie, L.; Slogrove, A. Current perspectives on paediatric HIV management from the Mexico International Aids Society Conference, 2019. S. Afr. J. HIV Med. 2019, 20, 5. [CrossRef]

61. Mulenga, P.; Mutanga, J. Follow-up of children HIV exposed uninfected through routine child health services: Zambian perspective. In Proceedings of the 5th Workshop on Children and Adolescents HIV Exposed and Uninfected, Mexico City, Mexico, 21 July 2019; International AIDS Society: Geneva, Switzerland, 2019.

62. Shiri, T.; Birungi, J.; Garrib, A.V.; Kivuyo, S.L.; Namakoola, I.; Mghamba, J.; Musinguzi, J.; Kimaro, G.; Mutungi, G.; Nyirenda, M.J.; et al. Patient and health provider costs of integrated HIV, diabetes and hypertension ambulatory health services in low-income settings-An empirical socio-economic cohort study in Tanzania and Uganda. BMC Med. 2021, 19, 230. [CrossRef] [PubMed] 
63. Moucheraud, C.; Hing, M.; Seleman, J.; Phiri, K.; Chibwana, F.; Kahn, D.; Schooley, A.; Moses, A.; Hoffman, R. Integrated care experiences and out-of-pocket expenditures: A cross-sectional survey of adults receiving treatment for HIV and hypertension in Malawi. BMJ Open 2020, 10, e032652. [CrossRef] [PubMed]

64. McGuire, F.; Vijayasingham, L.; Vassall, A.; Small, R.; Webb, D.; Guthrie, T.; Remme, M. Financing intersectoral action for health: A systematic review of co-financing models. Glob. Health 2019, 15, 86. [CrossRef]

65. Rosenberg, M.; Amisi, J.A.; Szkwarko, D.; Tran, D.N.; Genberg, B.; Luetke, M.; Kianersi, S.; Namae, J.; Laktabai, J.; Pastakia, S. The relationship between a microfinance-based healthcare delivery platform, health insurance coverage, health screenings, and disease management in rural Western Kenya. BMC Health Serv. Res. 2020, 20, 868. [CrossRef] [PubMed]

66. Woo, Y.L.; Gravitt, P.; Khor, S.K.; Ng, C.W.; Saville, M. Accelerating action on cervical screening in lower- and middle-income countries (LMICs) post COVID-19 era. Prev. Med. 2021, 144, 106294. [CrossRef]

67. Bernard, C.; Seydi, M.; Tanon, A.; Messou, E.; Minga, A.; Font, H.; Dabis, F. The International Epidemiological Database to evaluate Aids (IeDEA) West Africa Collaboration Barriers influencing task-shifting for the management of depression in people living with HIV: A study from West Africa IeDEA cohort collaboration. AIDS Care 2021, 33, 352-356. [CrossRef]

68. Aifah, A.; Onakomaiya, D.; Iwelunmor, J.; Oladele, D.; Gbajabiamila, T.; Obiezu-Umeh, C.; Nwaozuru, U.; Musa, A.Z.; Ezechi, O.; Ogedegbe, G. Nurses' perceptions on implementing a task-shifting/sharing strategy for hypertension management in patients with HIV in Nigeria: A group concept mapping study. Implement. Sci. Commun. 2020, 1, 58. [CrossRef]

69. Nyamayaro, P.; Bere, T.; Magidson, J.F.; Simms, V.; O’Cleirigh, C.; Chibanda, D.; Abas, M. A Task-Shifting Problem-Solving Therapy Intervention for Depression and Barriers to Antiretroviral Therapy Adherence for People Living With HIV in Zimbabwe: Case Series. Cogn. Behav. Pract. 2020, 27, 84-92. [CrossRef]

70. Udedi, M.; Stockton, M.A.; Kulisewa, K.; Hosseinipour, M.C.; Gaynes, B.N.; Mphonda, S.M.; Pence, B.W. The effectiveness of depression management for improving HIV care outcomes in Malawi: Protocol for a quasi-experimental study. BMC Public Health 2019, 19, 827. [CrossRef]

71. Udedi, M.; Stockton, M.A.; Kulisewa, K.; Hosseinipour, M.C.; Gaynes, B.N.; Mphonda, S.M.; Mwagomba, B.M.; Mazenga, A.C.; Pence, B.W. Integrating depression management into HIV primary care in central Malawi: The implementation of a pilot capacity building program. BMC Health Serv. Res. 2018, 18, 593. [CrossRef]

72. Dlamini-Simelane, T.; Moyer, E. Task shifting or shifting care practices? The impact of task shifting on patients' experiences and health care arrangements in Swaziland. BMC Health Serv. Res. 2017, 17, 20. [CrossRef]

73. Jobson, G.; Naidoo, N.; Matlakala, N.; Marincowitz, G.; Railton, J.; McIntyre, J.A.; Struthers, H.E.; Peters, R.P.H. Contextual factors affecting the integration of community health workers into the health system in Limpopo Province, South Africa. Int. Health 2019, 12, 281-286. [CrossRef]

74. Kredo, T.; Adeniyi, F.B.; Bateganya, M.; Pienaar, E.D. Task shifting from doctors to non-doctors for initiation and maintenance of antiretroviral therapy. Cochrane Database Syst. Rev. 2014, 2014, CD007331. [CrossRef] [PubMed]

75. Seidman, G.; Atun, R. Does task shifting yield cost savings and improve efficiency for health systems? A systematic review of evidence from low-income and middle-income countries. Hum. Resour. Health 2017, 15, 29. [CrossRef]

76. Kane, J.; Landes, M.; Carroll, C.; Nolen, A.; Sodhi, S. A systematic review of primary care models for non-communicable disease interventions in Sub-Saharan Africa. BMC Fam. Pract. 2017, 18, 46. [CrossRef] [PubMed]

77. Lovero, K.L.; Lammie, S.L.; Van Zyl, A.; Paul, S.N.; Ngwepe, P.; Mootz, J.J.; Carlson, C.; Sweetland, A.C.; Shelton, R.C.; Wainberg, M.L.; et al. Mixed-methods evaluation of mental healthcare integration into tuberculosis and maternal-child healthcare services of four South African districts. BMC Health Serv. Res. 2019, 19, 83. [CrossRef]

78. Limbani, F.; Thorogood, M.; Gómez-Olivé, F.X.; Kabudula, C.; Goudge, J. Task shifting to improve the provision of integrated chronic care: Realist evaluation of a lay health worker intervention in rural South Africa. BMJ Glob. Health 2019, 4, e001084 [CrossRef] [PubMed]

79. Goudge, J.; Chirwa, T.; Eldridge, S.; Gómez-Olivé, F.X.F.; Kabudula, C.; Limbani, F.; Musenge, E.; Thorogood, M. Can lay health workers support the management of hypertension? Findings of a cluster randomised trial in South Africa. BMJ Glob. Health 2018, 3, e000577. [CrossRef] [PubMed]

80. Ansbro, É.M.; Biringanine, M.; Caleo, G.; Prieto-Merino, D.; Sadique, Z.; Perel, P.; Jobanputra, K.; Roberts, B. Management of diabetes and associated costs in a complex humanitarian setting in the Democratic Republic of Congo: A retrospective cohort study. BMJ Open 2019, 9, e030176. [CrossRef] [PubMed]

81. Osetinsky, B.; Mwangi, A.; Pastakia, S.; Wilson-Barthes, M.; Kimetto, J.; Rono, K.; Laktabai, J.; Galárraga, O. Layering and scaling up chronic non-communicable disease care on existing HIV care systems and acute care settings in Kenya: A cost and budget impact analysis. J. Int. AIDS Soc. 2020, 23, e25496. [CrossRef]

82. Sam-Agudu, N.A.; Odiachi, A.; Bathnna, M.J.; Ekwueme, C.N.; Nwanne, G.; Iwu, E.N.; Cornelius, L.J. “They do not see us as one of them": A qualitative exploration of mentor mothers' working relationships with healthcare workers in rural North-Central Nigeria. Hum. Resour. Health 2018, 16, 47. [CrossRef]

83. Rabkin, M.; de Pinho, H.; Michaels-Strasser, S.; Naitore, D.; Rawat, A.; Topp, S.M. Strengthening the health workforce to support integration of HIV and noncommunicable disease services in sub-Saharan Africa. AIDS 2018, 32, S47-S54. [CrossRef]

84. Lawn, J.; Rohde, J.; Rifkin, S.; Were, M.; Paul, V.K.; Chopra, M. Alma-Ata 30 years on: Revolutionary, relevant, and time to revitalise. Lancet 2008, 372, 917-927. [CrossRef]

85. Braveman, P.; Gruskin, S. Poverty, equity, human rights and health. Bull. World Health Organ. 2003, 81, 539-545. 
86. Narasimhan, M.; Askew, I.; Vermund, S.H. Advancing sexual and reproductive health and rights of young women at risk of HIV. Lancet Glob. Health 2016, 4, e684-e685. [CrossRef]

87. South Africa National Department of Health (NDoH). Ideal Clinic Manual; Version 18; National Department of Health: Pretoria, South Africa, 2018.

88. Matanje Mwagomba, B.L.; Ameh, S.; Bongomin, P.; Juma, P.A.; MacKenzie, R.K.; Kyobutungi, C.; Lukhele, N.; Mwangi, K.J.; Amberbir, A.; Klipstein-Grobusch, K.; et al. Opportunities and challenges for evidence-informed HIV-noncommunicable disease integrated care policies and programs: Lessons from Malawi, South Africa, Swaziland and Kenya. AIDS 2018, 32 (Suppl. 1), S21-S32. [CrossRef] [PubMed]

89. Tollman, S. Community oriented primary care: Origins, evolution, applications. Soc. Sci. Med. 1991, 32, 633-642. [CrossRef]

90. Connor, E.; Mullan, F. Community Oriented Primary Care: New Directions for Health Services Delivery; Conference Proceedings; National Academies: Washington, DC, USA, 1983.

91. Hunter, J.R.; Chandran, T.M.; Asmall, S.; Tucker, J.-M.; Ravhengani, N.M.; Mokgalagadi, Y. The Ideal Clinic in South Africa: Progress and challenges in implementation. S. Afr. Health Rev. 2017, 2017, 111-123.

92. Bresick, G.; von Pressentin, K.B.; Mash, R. Evaluating the performance of South African primary care: A cross-sectional descriptive survey. South Afr. Fam. Pract. 2019, 61, 109-116. [CrossRef]

93. Massyn, N.; Barron, P.; Day, C.; Ndlovu, N.; Padarath, A. District Health Barometer 2018/19; Health Systems Trust: Durban, South Africa, 2020.

94. Muthathi, I.S.; Rispel, L.C. Policy context, coherence and disjuncture in the implementation of the Ideal Clinic Realisation and Maintenance programme in the Gauteng and Mpumalanga provinces of South Africa. Health Res. Policy Syst. 2020, 18, 55. [CrossRef]

95. Muthathi, I.S.; Levin, J.; Rispel, L.C. Decision space and participation of primary healthcare facility managers in the Ideal Clinic Realisation and Maintenance programme in two South African provinces. Health Policy Plan. 2020, 35, 302-312. [CrossRef] [PubMed]

96. Rawat, A.; Uebel, K.; Moore, D.; Cingl, L.; Yassi, A. Patient Responses on Quality of Care and Satisfaction with Staff After Integrated HIV Care in South African Primary Health Care Clinics. J. Assoc. Nurses AIDS Care 2018, 29, 698-711. [CrossRef] [PubMed]

97. Ameh, S.; Klipstein-Grobusch, K.; D’Ambruoso, L.; Kahn, K.; Tollman, S.M.; Gómez-Olivé, F.X. Quality of integrated chronic disease care in rural South Africa: User and provider perspectives. Health Policy Plan. 2016, 32, 257-266. [CrossRef]

98. Ameh, S.; D’Ambruoso, L.; Gómez-Olivé, F.X.; Kahn, K.; Tollman, S.; Klipstein-Grobusch, K. Paradox of HIV stigma in an integrated chronic disease care in rural South Africa: Viewpoints of service users and providers. PLoS ONE 2020, 15, e0236270. [CrossRef]

99. Lebina, L.; Oni, T.; Alaba, O.A.; Kawonga, M. A mixed methods approach to exploring the moderating factors of implementation fidelity of the integrated chronic disease management model in South Africa. BMC Health Serv. Res. 2020, 20, 617. [CrossRef]

100. Ameh, S.; Klipstein-Grobusch, K.; Musenge, E.; Kahn, K.; Tollman, S.; Gómez-Olivé, F.X. Effectiveness of an Integrated Approach to HIV and Hypertension Care in Rural South Africa: Controlled Interrupted Time-Series Analysis. JAIDS J. Acquir. Immune Defic. Syndr. 2017, 75, 472-479. [CrossRef]

101. Uebel, K.E.; Lombard, C.; Joubert, G.; Fairall, L.R.; Bachmann, M.O.; Mollentze, W.F.; van Rensburg, D.; Wouters, E. Integration of HIV care into primary care in South Africa: Effect on survival of patients needing antiretroviral treatment. J. Acquir. Immune Defic. Syndr. 2013, 63, e94-e100. [CrossRef]

102. Rawat, A.; Uebel, K.; Moore, D.; Yassi, A. Integrated HIV-Care into Primary Health Care Clinics and the Influence on Diabetes and Hypertension Care: An Interrupted Time Series Analysis in Free State, South Africa Over 4 Years. JAIDS J. Acquir. Immune Defic. Syndr. 2018, 77, 476-483. [CrossRef] [PubMed]

103. Haldane, V.; Legido-Quigley, H.; Chuah, F.L.H.; Sigfrid, L.; Murphy, G.A.V.; Ong, S.E.; Cervero-Liceras, F.; Watt, N.; Balabanova, D.; Hogarth, S.; et al. Integrating cardiovascular diseases, hypertension, and diabetes with HIV services: A systematic review. AIDS Care 2018, 30, 103-115. [CrossRef] [PubMed]

104. Lince-Deroche, N.; Leuner, R.; Kgowedi, S.; Moolla, A.; Madlala, S.; Manganye, P.; Xhosa, B.; Govathson, C.; Ndwanya, T.W.; Long, L. Voices from the front lines: A qualitative study of integration of HIV, tuberculosis, and primary healthcare services in Johannesburg, South Africa. PLoS ONE 2020, 15, e0230849. [CrossRef]

105. Heller, D.J.; Balzer, L.B.; Kazi, D.; Charlebois, E.D.; Kwarisiima, D.; Mwangwa, F.; Jain, V.; Kotwani, P.; Chamie, G.; Cohen, C.R.; et al. Hypertension testing and treatment in Uganda and Kenya through the SEARCH study: An implementation fidelity and outcome evaluation. PLoS ONE 2020, 15, e0222801. [CrossRef]

106. Kotwani, P.; Balzer, L.; Kwarisiima, D.; Clark, T.D.; Kabami, J.; Byonanebye, D.; Bainomujuni, B.; Black, D.; Chamie, G.; Jain, V.; et al. Evaluating linkage to care for hypertension after community-based screening in rural Uganda. Trop. Med. Int. Health 2014, 19, 459-468. [CrossRef] [PubMed]

107. Hyle, E.P.; Naidoo, K.; Su, A.E.; El-Sadr, W.M.; Freedberg, K.A. HIV, tuberculosis, and noncommunicable diseases: What is known about the costs, effects, and cost-effectiveness of integrated care? J. Acquir. Immune Defic. Syndr. 2014, 67 (Suppl. 1), S87-S95. [CrossRef] 
108. Ojo, T.; Lester, L.; Iwelunmor, J.; Gyamfi, J.; Obiezu-Umeh, C.; Onakomaiya, D.; Aifah, A.; Nagendra, S.; Opeyemi, J.; Oluwasanmi, M.; et al. Feasibility of integrated, multilevel care for cardiovascular diseases (CVD) and HIV in low- and middleincome countries (LMICs): A scoping review. PLoS ONE 2019, 14, e0212296. [CrossRef] [PubMed]

109. Onywera, H.; Mwapagha, L.; Hsiao, N.-Y. The need for a balanced hospital-based care (HBC) and home- and community-based care (HCBC) approach for mitigating COVID-19 pandemic in sub-Saharan Africa. Pan Afr. Med. J. 2021, 38. [CrossRef]

110. Anstey Watkins, J.; Griffiths, F.; Goudge, J. Community health workers' efforts to build health system trust in marginalised communities: A qualitative study from South Africa. BMJ Open 2021, 11, e044065. [CrossRef]

111. Bendavid, E.; Miller, G. The US Global Health Initiative: Informing policy with evidence. JAMA 2010, 304, 791-792. [CrossRef]

112. Gostin, L.O.; Mok, E.A. The President's Global Health Initiative. JAMA 2010, 304, 789-790. [CrossRef] [PubMed]

113. Hopkins, K.L.; Hlongwane, K.; Otwombe, K.; Dietrich, J.; Cheyip, M.; Khanyile, N.; Doherty, T.; Gray, G.E. Demographics and health profile on precursors of non-communicable diseases in adults testing for HIV in Soweto, South Africa: A cross-sectional study. BMJ Open 2019, 9, e030701. [CrossRef] [PubMed]

114. Hopkins, K.L.; Hlongwane, K.E.; Otwombe, K.; Dietrich, J.; Jaffer, M.; Cheyip, M.; Olivier, J.; Van Rooyen, H.; Wade, A.N.; Doherty, T.; et al. Does peer-navigated linkage to care work? A cross-sectional study of active linkage to care within an integrated non-communicable disease-HIV testing centre for adults in Soweto, South Africa. PLoS ONE 2020, 15, e0241014. [CrossRef] [PubMed]

115. Mazhin, S.A.; Khankeh, H.; Farrokhi, M.; Aminizadeh, M.; Poursadeqiyan, M. Migration health crisis associated with climate change: A systematic review. J. Educ. Health Promot. 2020, 9, 97. [CrossRef]

116. Lieber, M.; Chin-Hong, P.; Kelly, K.; Dandu, M.; Weiser, S.D. A systematic review and meta-analysis assessing the impact of droughts, flooding, and climate variability on malnutrition. Glob. Public Health 2020, 2020, 1-15. [CrossRef]

117. Anenberg, S.C.; Haines, S.; Wang, E.; Nassikas, N.; Kinney, P.L. Synergistic health effects of air pollution, temperature, and pollen exposure: A systematic review of epidemiological evidence. Environ. Health 2020, 19, 130. [CrossRef]

118. Chersich, M.F.; Pham, M.D.; Areal, A.; Haghighi, M.M.; Manyuchi, A.; Swift, C.P.; Wernecke, B.; Robinson, M.; Hetem, R.; Boeckmann, M.; et al. Associations between high temperatures in pregnancy and risk of preterm birth, low birth weight, and stillbirths: Systematic review and meta-analysis. BMJ 2020, 371, m3811. [CrossRef]

119. Shea, E.; Perera, F.; Mills, D. Towards a fuller assessment of the economic benefits of reducing air pollution from fossil fuel combustion: Per-case monetary estimates for children's health outcomes. Environ. Res. 2020, 182, 109019. [CrossRef]

120. Tidman, R.; Abela-Ridder, B.; de Castañeda, R.R. The impact of climate change on neglected tropical diseases: A systematic review. Trans. R. Soc. Trop. Med. Hyg. 2021, 115, 147-168. [CrossRef]

121. Cruz, J.; White, P.C.L.; Bell, A.; Coventry, P.A. Effect of Extreme Weather Events on Mental Health: A Narrative Synthesis and Meta-Analysis for the UK. Int. J. Environ. Res. Public Health 2020, 17, 8581. [CrossRef]

122. Mellet, J.; Pepper, M.S. A COVID-19 Vaccine: Big Strides Come with Big Challenges. Vaccines 2021, 9, 39. [CrossRef]

123. Nhamo, G.; Chikodzi, D.; Kunene, H.P.; Mashula, N. COVID-19 vaccines and treatments nationalism: Challenges for low-income countries and the attainment of the SDGs. Glob. Public Health 2021, 16, 319-339. [CrossRef]

124. Members LCoC-VaTTF. Urgent needs of low-income and middle-income countries for COVID-19 vaccines and therapeutics. Lancet 2021, 397, 562-564. [CrossRef]

125. Mejia, R.; Hotez, P.; Bottazzi, M.E. Global COVID-19 Efforts as the Platform to Achieving the Sustainable Development Goals. Curr. Trop. Med. Rep. 2020, 7, 99-103. [CrossRef] [PubMed]

126. Carlucci, J.; Liu, Y.; Clouse, K.; Vermund, S.H. Attrition of HIV-positive children from HIV services in low and middle-income countries. AIDS 2019, 33, 2375-2386. [CrossRef]

127. Audet, C.M.; Groh, K.; Moon, T.; Vermund, S.H.; Sidat, M. Poor-quality health services and lack of programme support leads to low uptake of HIV testing in rural Mozambique. Afr. J. AIDS Res. 2012, 11, 327-335. [CrossRef]

128. Bravo, M.P.; Peratikos, M.M.B.; Muicha, M.A.S.; Mahagaja, E.; Alvim, M.F.S.; Green, A.F.; Wester, C.W.; Vermund, S.H. Monitoring Pharmacy and Test Kit Stocks in Rural Mozambique: U.S. President's Emergency Plan for AIDS Relief Surveillance to Help Prevent Ministry of Health Shortages. AIDS Res. Hum. Retrovir. 2020, 36, 415-426. [CrossRef]

129. Ciampa, P.J.; Tique, J.; Jumá, N.; Sidat, M.; Moon, T.D.; Rothman, R.L.; Vermund, S.H. Addressing poor retention of infants exposed to HIV: A quality improvement study in rural Mozambique. J. Acquir. Immune Defic. Syndr. 2012, 60, e46-e52. [CrossRef]

130. Aliyu, M.H.; Blevins, M.; Audet, C.M.; Kalish, M.; Gebi, U.I.; Onwujekwe, O.; Lindegren, M.L.; Shepherd, B.E.; Wester, C.W.; Vermund, S.H. Integrated prevention of mother-to-child HIV transmission services, antiretroviral therapy initiation, and maternal and infant retention in care in rural north-central Nigeria: A cluster-randomised controlled trial. Lancet HIV 2016, 3, e202-e211. [CrossRef]

131. Audet, C.M.; Blevins, M.; Chire, Y.M.; Aliyu, M.; Vaz, L.M.E.; Antonio, E.; Alvim, F.; Bechtel, R.; Wester, C.W.; Vermund, S. Engagement of Men in Antenatal Care Services: Increased HIV Testing and Treatment Uptake in a Community Participatory Action Program in Mozambique. AIDS Behav. 2016, 20, 2090-2100. [CrossRef]

132. Tankwanchi, A.B.; Ozden, C.; Vermund, S.H. Physician emigration from sub-Saharan Africa to the United States: Analysis of the 2011 AMA physician masterfile. PLoS Med. 2013, 10, e1001513. [CrossRef] 
133. Tankwanchi, A.S.; Hagopian, A.; Vermund, S.H. African Physician Migration to High-Income Nations: Diverse Motives to Emigrate ("We Are not Florence Nightingale") or Stay in Africa ("There Is No Place Like Home") Comment on "Doctor Retention: A Cross-sectional Study of How Ireland Has Been Losing the Battle". Int. J. Health Policy Manag. 2020, 10, 660-663. [CrossRef]

134. Tankwanchi, A.B.; Vermund, S.H.; Perkins, D.D. Has the WHO Global Code of Practice on the International Recruitment of Health Personnel been effective? Lancet Glob. Health 2014, 2, e390-e391. [CrossRef] 